ORL 1991;53:181-183

\title{
Contents, Vol. 53, No. 4, 1991
}

\section{Preface 184}

Terminology and Classification of Neuroendocnne Neoplasms of the

\section{Larynx}

Ferlito, A.; Rosai, J 185

Carcinoid Tumor of the Larynx. A Critical Review of the Literature

El-Naggar, A.K.; Batsakis, J.G

Atypical Carcinoid Tumor of the Larynx. A Critical Review of the

Literature

Woodruff, J.M.; Senie, R.T 194

Small Cell Neuroendocnne Carcinoma of the Larynx. A Critical Review

of the Literature

Gnepp,D.R 210

Paraganglioma of the Larynx. A Critical Review of the Literature

Barnes, L 220

Contribution of Immunohistochemistry in the Diagnosis of Neuroendocnne Neoplasms of the Larynx

Ferlito, A.; Friedmann, 1

Nuclear Ploidy in Neuroendocnne Neoplasms of the Larynx

Milroy, CM.; Williams, R.A.; Charlton, I.G.; Moss, E.; Rode, J 245

Neurological Manifestations of Neuroendocnne Neoplasms of the

Larynx

Deleu, D.; De Geeter, F 250

Treatment of Neuroendocnne Neoplasms of the Larynx

Moisa, I.I.; Silver, C.E 259 Neuroendocrine Neoplasms of the Larynx

Guest Editor: Alfio Ferlito, Padua

43 figures and 21 tables, 1991

KAHGEK

S. Karger Medical and Scientific Publishers

Basel · München · Paris ' London · New York · New Delhi · Bangkok · Singapore · Tokyo ·

Sydney

Drug Dosage

The authors and the publisher have exerted every effort to ensure that drug selection and dosage set forth in this text are in accord with current recommendations and practice at the time of publication. However, in view of ongoing research, changes in government regulations, and the constant flow of information relating to drug therapy and drug reactions, the reader is urged to check the package insert for each drug for any change in indications and dosage and for added warnings and precautions. This is particularly important when the recommended agent is a new and/or infrequently employed drug.

All rights reserved. 
No part of this publication may be translated into other languages, reproduced or utilized in any form or by any means, electronic or mechanical, including photocopying, recording, microcopying, or by any information storage and retrieval system, without permission in writing from the publisher or, in the case of photocopying, direct payment of a specified fee to the Copyright Clearance Center (see 'Information for Readers and Subscribers').

(C) Copyright 1991 by S. Karger AG, P.O. Box, CH- 4009 Basel (Switzerland) Printed in Switzerland on acid-free paper by Thür AG Offsetdruck, Pratteln ISBN 3-8055-5445-1 